LLL' BANCO CENTRAL DO BRASIL

\title{
Monetary Policy and Reserve Requirements in a Small Open Economy
}

Carlos Alberto Takashi Haraguchi and Jose Angelo Divino

January 2020

Working Papers
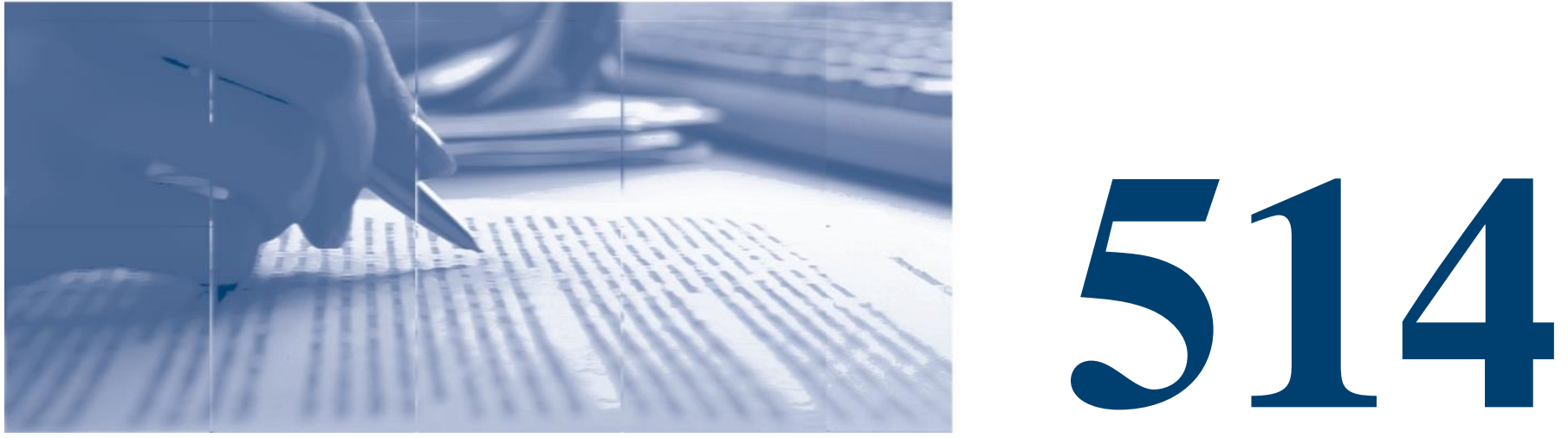


\section{Working Paper Series}

Edited by the Research Department (Depep) - E-mail: workingpaper@bcb.gov.br

Editor: Francisco Marcos Rodrigues Figueiredo

Co-editor: José Valentim Machado Vicente

Head of the Research Department: André Minella

Deputy Governor for Economic Policy: Fabio Kanczuk

The Banco Central do Brasil Working Papers are evaluated in double blind referee process.

Although the Working Papers often represent preliminary work, citation of source is required when used or reproduced.

The views expressed in this Working Paper are those of the authors and do not necessarily reflect those of the Banco Central do Brasil.

As opiniões expressas neste trabalho são exclusivamente do(s) autor(es) e não refletem, necessariamente, a visão do Banco Central do Brasil.

\section{Citizen Service Division}

Banco Central do Brasil

Deati/Diate

SBS - Quadra 3 - Bloco B - Edifício-Sede - $2^{\circ}$ subsolo

70074-900 Brasília - DF - Brazil

Toll Free: 08009792345

Fax: +55 (61) 3414-2553

Internet: http//www.bcb.gov.br/?CONT ACT US 


\section{Non-Technical Summary}

The financial sector is a source and channel of transmission of crises to the real side of the economy. This role was dramatically highlighted during the subprime crisis. Since then, many researchers have been looking more carefully at the financial sector and the adoption of macroprudential measures such as reserve requirements policy. Some works, for instance, suggest emerging market central banks avoid raising interest rates when facing credit booms and prefer to use reserve requirements as an additional policy instrument. Nevertheless, macroprudential measures were adopted simultaneously to other standard monetary policy actions, giving rise to a discussion on whether they are complementary or substitute, and what their combined effects on the real side of the economy are. This paper investigates how a combination of monetary policy based on interest rate rules and a macroprudential policy of reserve requirements might affect the dynamics of a small open economy with financial frictions under alternative exogenous shocks. The theoretical model is calibrated and simulated for the Brazilian Economy as a typical case of a major emerging market economy that has actively used macroprudential policy under the inflation targeting regime. The main results indicate complementarity between monetary and macroprudential policies to stabilize the small open economy. The exchange rate plays a central role in the transmission of foreign shocks, but not of domestic shocks. Considering stability of the variables, the interest rate rule should target domestic inflation and not respond directly to the exchange rate. The reserve requirement rule, in its turn, should react countercyclically to the credit-gap and not have a fixed component. 


\section{Sumário Não Técnico}

O setor financeiro é uma fonte e um canal de transmissão de crises para o setor real da economia. Este papel foi amplamente destacado na crise do subprime. Desde então, muitos pesquisadores têm prestado mais atenção ao setor financeiro e à adoção de medidas macroprudenciais, tais como a política de requerimento de depósitos compulsórios. Alguns trabalhos, por exemplo, sugerem que bancos centrais de países emergentes evitam elevar a taxa de juros em situações de explosão de crédito e preferem usar os depósitos compulsórios como um intrumento adicional de política. Não obstante, medidas macroprudenciais foram adotadas simultaneamente a outras ações de políticas monetárias convencionais, fazendo emergir a discussão sobre o caráter complementar ou substituto dessas politicas e quais são seus efeitos combinados sobre o setor real da economia. Este artigo investiga como uma combinação de política monetária baseada em regras de taxa de juros e uma política macroprudencial de depósitos compulsórios podem afetar a dinâmica de uma pequena economia aberta que experimenta friç̧ões no setor financeiro e recebe diferentes choques exógenos. O modelo teórico é calibrado e simulado para a economia brasileira como o caso típico de uma importante economia emergente que usou ativamente a política macroprudencial no período do regime de metas de inflação. Os principais resultados revelam uma complementariedade entre as políticas monetária e macroprudencial para estabilizar a pequena economia aberta. A taxa de câmbio desempenha um papel central na transmissão de choques externos mas não em choques domésticos. Considerando a estabilidade das variáveis, a regra de taxa de juros deveria ter como meta uma inflação doméstica e não responder diretamente à taxa de câmbio. A regra de depósitos compulsórios, por sua vez, deveria reagir de maneira contracíclica ao desvio do crédito em vez de utilizar somente uma alíquota fixa. 


\title{
Monetary policy and reserve requirements in a small open economy *
}

\author{
Carlos Alberto Takashi Haraguchi ${ }^{\dagger}$ \\ Jose Angelo Divino $\ddagger$
}

\begin{abstract}
This paper investigates how a combination of monetary and macroprudential policies might affect the dynamics of a small open economy with financial frictions under alternative exogenous shocks. The proposed DSGE model incorporates macroprudential policy rules to the financial sector of an open economy. Exogenous shocks in productivity, domestic and foreign monetary policies are used to identify the roles of the macroprudential and monetary policies in stabilizing the economy. A welfare analysis compares the performance of alternative rules for reserve requirements. The model is calibrated for the Brazilian economy and results indicate the exchange rate plays a central role in the transmission of foreign shocks, but not of domestic shocks. Considering the volatility of the variables and convergence to steady state, the interest rate rule should target domestic inflation and not respond directly to the exchange rate. The reserve requirement rule, in its turn, should react countercyclically to the credit-gap and not have a fixed component. There is complementarity between monetary and macroprudential policies to stabilize the small open economy.
\end{abstract}

Keywords: Monetary policy; Macroprudential policy; Small Open economy; Financial frictions.

JEL Classification: E44; E58; E52; F41.

The Working Papers should not be reported as representing the views of the Banco Central do Brasil. The views expressed in the papers are those of the author(s) and do not necessarily reflect those of the Banco Central do Brasil.

* The authors would like to thank the participants in the XXXVIII Brazilian Meeting of the Econometric Society and XVII Latin American Workshop in Economic Theory for valuable comments and suggestions. C. Haraguchi thanks CAPES Foundation and J. A. Divino thanks CNPq for financial support. This study was financed in part by the Coordenação de Aperfeiçoamento de Pessoal de Nível Superior - Brasil (CAPES) - Finance Code 001. All remaining errors are the authors sole responsibility.

${ }^{\dagger}$ Central Bank of Brasil and Catholic University of Brasilia. E-mail: carlos.takashi@bcb.gov.br.

$\ddagger$ Corresponding author. Catholic University of Brasilia. SGAN 916, office A-118, ZIP: 70.790160, Brasilia-DF, Brazil. E-mail: jangelo@pos.ucb.br. 


\section{Introduction}

Over the past few years, since the 2008 financial turmoil, both developed and developing countries have adopted a mix of macroprudential and monetary policy actions as part of a prescription to recover their economies from the negative effects of the crisis. The Central Bank of Brazil, for instance, implemented a reserve requirements policy to prevent the economy from a credit contraction. Later on, following the country's recovery, this policy was used to reduce the speed of expansion of the credit market. Other policy instruments such as minimum capital requirements were also applied as countercyclical tools to manage credit fluctuations. These macroprudential measures were adopted simultaneously to other standard monetary policy actions, giving rise to a discussion on whether they are complementary or substitute, and what their combined effects on the real side of the economy are. ${ }^{1}$

The subprime crisis highlighted the role of the financial sector as a source and channel of transmission of crises to the real side of the economy. Since then, many researchers have been looking more carefully at the financial sector and building models with different kinds of financial frictions. The relationship between equity capital of banks and credit flow, for instance, was modelled by Gertler and Karadi (2011), who incorporated financial intermediaries in a DSGE model with nominal rigidities based on Christiano et al. (2005) and Smets and Wouters (2007). The financial friction was incorporated in the closed economy as an agency problem between financial intermediaries and savers, inducing an endogenous restriction on the degree of leverage so that a deterioration in the bank's capital triggers an imbalance between supply and demand and an increase in the cost of credit.

Another element that affects credit flow is reserve requirements by the monetary authority. As argued by Glocker and Towbin (2015), emerging market central banks avoid raising interest rates when facing credit booms and prefer to use reserve requirements as an additional policy instrument. Divino and Kornelius (2015), using the Gertler and Karadi (2011) framework, added policy rules for reserve requirements to the baseline model of a closed economy. They calibrated the model for the Brazilian economy and found the macroprudential policy of reserve requirements is not a substitute for conventional monetary policy based on interest rate rules. However, it might be a complementary tool to stabilize credit conditions and minimize volatility of macroeconomic variables under domestic shocks.

In the open economy environment, the role of the macroprudential policy has not been widely explored yet. A relevant question to answer is whether it might contribute to stabilize the real sector of the economy and to produce higher welfare

\footnotetext{
${ }^{1}$ See Glocker and Towbin (2015) for a detailed discussion on the macroprudential and monetary policies adopted by the Central Bank of Brazil under the inflation targeting regime.
} 
than the sole use of standard monetary policy instruments. Gali and Monacelli (2005) investigated macroeconomic implications of distinct monetary policy regimes and found a trade-off between exchange rate and terms of trade stabilization on the one hand, and domestic inflation and output gap on the other. Under their set-up, domestic inflation targeting emerges as the optimal monetary policy regime relatively to both Taylor rules and exchange rate peg, which generate higher welfare losses due to the excessive smoothness in the terms of trade that they entail. Using a similar framework, Divino (2009b) claims the real exchange rate affects inflation and output gap in opposite directions, yielding an endogenous monetary policy tradeoff that makes it impossible for the monetary authority to stabilize both of these variables simultaneously. Furthermore, the optimal monetary policy is accompanied by a dirty floating of the exchange rate, where a Taylor type of interest rate rule is indirectly affected by changes in the real exchange rate.

Recent studies emphasize financial stability should be the primary objective of the macroprudential policy, instead of price and output-gap stabilization, which are conventional objectives of the monetary policy (Divino and Kornelius, 2015; Glocker and Towbin, 2012; Agénor et al., 2013). However, macroprudential measures might improve the performance of the monetary policy in the presence of financial frictions and under the goal of financial stability by the central bank, when this objective is explicitly accounted for in the interest rate rule (Glocker and Towbin, 2012), in the reserve requirements rule (Divino and Kornelius, 2015), or in the capital requirements rule (Agénor et al., 2013). Reserve requirements are very effective and easily implemented in practice (Carvalho and Castro, 2015b; Agénor et al., 2015) and should respond to credit growth in some extent (Ferreira and Nakane, 2015).

The objective of this paper is to investigate how a combination of a monetary policy based on interest rate rules and macroprudential policy grounded on reserve requirements might affect the dynamics of a small open economy with financial frictions under alternative exogenous shocks. The external sector is incorporated to a DSGE (dynamic stochastic general equilibrium) model with macroprudential policy rules. Domestic households might invest in foreign risk-free bonds, and exchange rate movements are transmitted to domestic prices through wage inflation. Exogenous shocks in domestic monetary policy, productivity, and foreign monetary policy are used to simulate the dynamics and identify the roles of macroprudential and monetary policies to stabilize the small open economy. The monetary policy sets nominal interest rate rules that react to different measures of inflation and exchange rate. The model is calibrated for the Brazilian economy because it is a representative case of an emerging economy that used reserve requirements as a macroprudential tool in several episodes in the post-2000 period, as detailed by Glocker and Towbin 
(2015). ${ }^{2}$ After identifying the best design for the monetary policy rule, we confront it with alternative macroprudential policy arrangements, represented by reserve requirements rules that combine a fixed rate with a varying component that reacts to the credit gap. A welfare analysis compares the performances of the alternative monetary and macroprudential policies to stabilize the small open economy.

The model brings together elements of financial frictions, macroprudential policy, and open economy in an unified environment. The major results indicate the exchange rate plays a relevant role on the transmission of exogenous shocks originated only in the foreign sector. For the domestic shocks, there are no significant differences between the dynamics of the small open and closed economies. That is because the rest of the world economy is exogenous to the small open economy and the degree of openness is small, as is the case of the Brazilian economy. Thus, the interest rate rule should not directly respond to the exchange rate after either domestic or foreign shocks. The best choice for the monetary policy is a domestic inflation targeting regime; while for the macroprudential policy, it is a reserve requirements rule that reacts more aggressively to deviations in the credit-gap. Reserve requirements should be used as a systematic countercyclical macroprudential instrument instead of an ad-hoc policy tool on which policy-makers can rely only during episodes of capital inflows. This finding is in line with the literature that, considering a wider set of macroprudential instruments, recommends the adoption of more aggressive policy rules (Gertler and Karadi, 2011; Ferreira and Nakane, 2015; Clancy and Merola, 2017). The combination of those policies yields the highest welfare improvement to the society. Thus, there is a complementarity between monetary and macroprudential policies to reach economic stability after distinct exogenous shocks hit the small open economy.

The paper is organized as follows. The next section describes the baseline model, with emphasis on the new elements represented by the financial sector, macroprudential policy, and openness of the economy. The third section describes the parameters used in calibration, reports and discusses the results obtained from the simulation exercises. Finally, the fourth section is dedicated to the concluding remarks.

\section{Model}

The benchmark consists of a New Keynesian DSGE model with financial friction and reserve requirements. The financial sector is modelled according to Gertler and Karadi (2011), where banks lend funds obtained from households to firms. Financial

\footnotetext{
${ }^{2}$ Actually, in advanced economies, the conventional monetary policy tool is the short-term interest rate and central banks no longer use reserve requirements as monetary policy instruments (Montoro and Moreno, 2011; Brei and Moreno, 2018). Nowadays this is also true for most emerging countries.
} 
intermediaries are also a source of financial frictions in the credit market. Reserve requirements follow the set up proposed by Agénor et al. (2015) and Divino and Kornelius (2015). The model is developed for two asymmetric countries represented by a small open economy (SOE) and the rest of the world (ROW). In this configuration, residents of the SOE have access to imported final goods and risk-free bonds denominated in foreign currency.

\subsection{Households}

The representative household is composed of workers and bankers in constant proportions over time. Workers supply labour and earn wages in return. Bankers run financial intermediaries and make lump sum transfers of all earnings to their respective households, who might save by buying debt from financial intermediaries and consume final goods. Saving might also be negative, meaning that they are borrowing from financial intermediaries. Assuming that there is a continuum of identical households in the unit interval, the problem is to maximize the expected discounted value of the utility function, given by

$$
\max \sum_{i=0}^{\infty} \beta^{i} E_{t}\left[u\left(C_{t+i}, L_{t+i}\right)\right]
$$

where $C_{t}$ is consumption and $L_{t}$ is labour supply. Following Gali (2008), consumption is a composite $C_{t} \equiv\left[(1-\alpha)^{\frac{1}{\eta}}\left(C_{H, t}\right)^{\frac{\eta-1}{\eta}}+\alpha^{\frac{1}{\eta}}\left(C_{F, t}\right)^{\frac{\eta-1}{\eta}}\right]^{\frac{\eta}{\eta-1}}$ of domestically produced goods $C_{H, t}$ and imported final goods $C_{F, t}$, where $\alpha$ is referred to as the degree of openness of the $\operatorname{SOE}(0 \leq \alpha \leq 1)$ and $\eta>0$ measures the substitutability between domestic and foreign produced goods, from the viewpoint of the domestic consumer. The standard utility function incorporates habit formation and depends on consumption and labour supply as $u\left(C_{t}, L_{t}\right)=\log \left(C_{t}-h C_{t-1}\right)-\frac{\chi}{1+\varphi} L_{t}^{1+\varphi}$ where $h$ is the habit formation parameter $(0<h<1), \chi$ is the relative weight placed on labour supply, and $\varphi$ is the Frisch elasticity of labour supply $(\chi, \varphi>0)$.

Households face a home currency budget constraint ${ }^{3}$ :

$$
C_{t}+B_{t+1}+\epsilon_{t} B_{t+1}^{*}=W_{t} L_{t}+T_{t}+R_{t} B_{t}+\epsilon_{t} R_{t}^{*} B_{t}^{*},
$$

where $B_{t}$ is the quantity of domestic short-term debt, $B_{t}^{*}$ is the amount of risk-free foreign bonds (both bonds with maturity in $t$ ), $\epsilon_{t}$ is the real exchange rate, $W_{t}$ is the real wage, $T_{t}$ denotes lump-sum transfers and pay-offs to the households from ownership of firms, $R_{t}$ is the risk-free gross real return of domestic bonds, $R_{t}^{*}$ is the gross foreign real interest rate paid by the foreign bond, and $\beta$ is the constant

\footnotetext{
${ }^{3}$ There is no fiscal policy in the economy, as our focus is on monetary and macroprudential policies.
} 
intertemporal discount factor $(0<\beta<1)$.

The first-order condition (FOC) for labour supply is:

$$
U M g C_{t} W_{t}=\chi L_{t}^{\varphi}
$$

where the marginal utility of consumption $\left(U M g C_{t}\right)$ is:

$$
U M g C_{t}=\left(C_{t}-h C_{t-1}\right)^{-1}-\beta h E_{t}\left(C_{t+1}-h C_{t}\right)^{-1} .
$$

The FOC for domestic short-term bond $\left(B_{t+1}\right)$ yields the Euler equation:

$$
E_{t}\left[\beta \Lambda_{t, t+1} R_{t+1}\right]=1,
$$

where the stochastic discount factor $\left(\Lambda_{t, t+1}\right)$ is defined as:

$$
\Lambda_{t, t+1} \equiv \frac{U M g C_{t+1}}{U M g C_{t}}
$$

Finally, the FOC for risk-free foreign bond $B_{t+1}^{*}$ yields:

$$
E_{t}\left[\beta \Lambda_{t, t+1} \frac{\epsilon_{t+1}}{\epsilon_{t}} R_{t+1}^{*}\right]=1
$$

\subsection{Non-financial firms}

Non-financial firms are categorized in three groups, represented by intermediate goods producing firms, capital producing firms, and final goods producing firms. Intermediate goods firms borrow from financial intermediaries, buy capital from capital producing firms, and sell intermediate goods to final goods firms, receiving $P_{m}$ for each unit sold. Capital producing firms buy capital from intermediate goods firms, repair depreciated capital, build new capital, and sell new and refurbished capital to intermediate goods firms. Final goods firms buy intermediate goods, re-package and sell them to the final consumers.

\subsubsection{Intermediate goods producing firms}

Intermediate goods firms are competitive firms that produce and sell intermediate goods to final goods firms, using labour supplied by households and capital produced by capital producing firms. To buy capital, intermediate goods firms obtain loans from financial intermediaries. At the end of each period, they sell depreciated capital back to capital producing firms and buy a new one for use in production in the subsequent period. 
The loans are completely used to buy capital:

$$
Q_{t} S_{t}=Q_{t} K_{t+1}
$$

where $S_{t}$ is the amount of financial claims, $K_{t+1}$ is the capital acquired at the end of period $t$ for use in production in the next period, and $Q_{t}$ is the value of each unit of loan as well as the price of each unity of capital. ${ }^{4}$ There are no financial frictions such as collateral restrictions for firms to obtain loans from financial intermediaries. It is assumed that financial intermediaries have complete information about the firms and there is no problem for enforcing payouts as in Gertler and Karadi (2011).

The technology of intermediate goods firms is described by the production function $^{5}$ :

$$
Y_{m t}=A_{t}\left(U_{t} K_{t}\right)^{\alpha_{c}} L_{t}^{1-\alpha_{c}}
$$

where $Y_{m t}$ is the aggregate production of intermediate goods, $A_{t}$ is the total factor productivity, $U_{t}$ is the utilization rate of capital, $K_{t}$ is the available capital to the firm, and $\alpha_{c}$ is the share of capital in the Cobb-Douglas function. Productivity $A_{t}$ is subject to an exogenous shock modelled as a stationary log-linear first-order autoregressive process:

$$
\log A_{t}=\rho_{A} \log A_{t-1}+\varepsilon_{A t},
$$

where $\rho_{A} \in(0,1)$ and $\varepsilon_{A t} \sim \operatorname{iid}\left(0, \sigma_{A}^{2}\right)$.

Capital evolves from the addition of net investment to the effective quantity of capital held from the previous period:

$$
K_{t+1}=K_{t}+I_{n t}
$$

Suppose that at the end of period $t$, capital producing firms repurchase remaining capital $K_{t}$ under the current price $Q_{t}\left(Q_{t} K_{t}\right)$ and discounted by depreciation. Hence, the profit of the firm is the total income minus costs of labour and financial claims plus remaining capital, as follows:

$$
\text { Profit }_{m t}=P_{m t} Y_{m t}-W_{t} L_{t}-Q_{t-1} S_{t-1} R_{k t}+\left[Q_{t}-\delta\left(U_{t}\right)\right] K_{t},
$$

where $P_{m t}$ is the price of the intermediate good, $\delta\left(U_{t}\right)$ is the depreciation rate, $R_{k t}$ is the gross return of the financial claims $Q_{t-1} S_{t-1}$ with maturity in $t, P_{m t} Y_{m t}$ is

\footnotetext{
${ }^{4}$ The prices of the financial claim and capital are equal to simplify the problem. To make this feasible, it is enough to adjust either the value of financial claims or the price of capital, so that the unity values are the same.

${ }^{5}$ We abstract from an exogenous shock in the quality of capital, $\xi_{t}$, that appears in Gertler and Karadi (2011) because it plays no role in our set up.
} 
the income, and $\left[Q_{t}-\delta\left(U_{t}\right)\right] K_{t}$ is the stock of capital that is left over, discounted the depreciation rate. The depreciation rate is a crescent and convex function of utilization rate of capital $U_{t}$, such that:

$$
\delta\left(U_{t}\right)=\delta_{a}+\delta_{b} \frac{U_{t}^{1+\zeta}}{1+\zeta}
$$

where $\delta_{a}$ is the depreciation even if capital was not used, $\delta_{b}$ and $\zeta>0$ are parameters of the function.

In a monopolistic competitive market, prices of goods and quantities of inputs (labour and utilization rate of capital) are chosen by private agents in order to maximize profit subjected to the production technology described in equation (7), for $t=0,1, \ldots$ The FOC's for profit maximization are:

$$
P_{m t}\left(1-\alpha_{c}\right) \frac{Y_{m t}}{L_{t}}=W_{t}
$$

and

$$
P_{m t} \alpha c \frac{Y_{m t}}{U_{t}}=\delta_{b} U_{t}^{\zeta} K_{t}
$$

using equation (11) to replace $\delta^{\prime}\left(U_{t}\right)$. In order to endogenously determine the return of financial claims, it is assumed that financial intermediaries have perfect information about the firm so that they charge the ex-post return on capital in an amount that exactly offsets profits in $t+1$. Substituting equations (6) and (12) in (13), and rearranging, we obtain:

$$
R_{k t+1}=\frac{\left[P_{m t+1} \alpha_{c} \frac{Y_{m t+1}}{K_{t+1}}-\delta\left(U_{t+1}\right)+Q_{t+1}\right]}{Q_{t}} .
$$

\subsubsection{Capital producing firms}

The capital producing firms buy capital from intermediate goods firms at the end of the period, repair what was depreciated and build new capital. New and refurbished capital form the gross capital or gross investment of the economy. Then, capital producing firms sell the gross capital stock to the same intermediate goods firms. They face adjustment costs associated with new capital, but not with refurbished capital, which has unity cost. Profits are distributed to the respective owners of the firms via lump sum transfers.

The net capital created, or net investment $I_{n t}$, is defined as the difference between gross investment $I_{t}$ and refurbished capital $\delta\left(U_{t}\right) K_{t}$ :

$$
I_{n t} \equiv I_{t}-\delta\left(U_{t}\right) K_{t} .
$$


Adjustment cost of the net investment $I_{n t}$ fulfils the properties $f(1)=f^{\prime}(1)=0$ and $f^{\prime \prime}(1)>0$, and has functional form as

$$
f\left(\frac{I_{n t}+I_{s s}}{I_{n t-1}+I_{s s}}\right)=\frac{\eta_{i}}{2}\left(\frac{I_{n t}+I_{s s}}{I_{n t-1}+I_{s s}}-1\right)^{2}
$$

where $I_{s s}$ is the steady-state investment and $\eta_{i}>0$ is the inverse of net investment elasticity with respect to capital price in the steady state.

The profit of capital producing firms is the expected value of income from the net capital at price $Q_{t}$ minus the unit cost of produced capital and adjustment cost, represented by

$$
\operatorname{Profit}_{k t}=E_{t} \sum_{i=0}^{\infty} \beta^{i} \Lambda_{t, t+i}\left[Q_{t+i} I_{n t+i}-I_{n t+i}-f\left(\frac{I_{n t+i}+I_{s s}}{I_{n t+i-1}+I_{s s}}\right)\left(I_{n t+i}+I_{s s}\right)\right] .
$$

Profit only comes from created net capital, given that refurbished capital is sold by unity price, which is the same price of cost, to intermediate goods firms.

The problem of capital producing firms is to choose the optimal level of net investment $I_{n t}$ in order to maximize profits subject to the definition of net capital created (15). The price $Q_{t}$ is given because one assumes a competitive market. The FOC yields:

$$
Q_{t}=1+f(\cdot)+\frac{I_{n t}+I_{s s}}{I_{n t-1}+I_{s s}} f^{\prime}(\cdot)-E_{t}\left[\beta \Lambda_{t, t+1}\left(\frac{I_{n t+1}+I_{s s}}{I_{n t}+I_{s s}}\right)^{2} \eta_{i}\left(\frac{I_{n t+1}+I_{s s}}{I_{n t}+I_{s s}}-1\right)\right]
$$

\subsubsection{Final goods producing firms}

Non-differentiated goods produced by intermediate goods firms are inputs used in the production process of final goods. Final goods firms re-package these intermediate goods as differentiated goods and sell them to the final consumers. There is friction in nominal prices as long as final goods firms have market power due to the production of differentiated goods. Final good price is adjusted above marginal cost according to a time dependent rule proposed by Calvo (1983).

The production is a constant elasticity of substitution function (CES) of a continuum of unit mass of final goods firms, where each firm produces a sole differentiated final good. Specifically, we have that $Y_{t}=\left[\int_{0}^{1} Y_{f t}^{\frac{\varepsilon-1}{\varepsilon}} d f\right]^{\frac{\varepsilon}{\varepsilon-1}}$, where $Y_{t}$ is the aggregate final output, $Y_{f t}$ is the output of firm $f$, and $\varepsilon$ is the constant elasticity of substitution, with $\varepsilon>1$. The price of the final goods is $\int_{0}^{1} P_{f t} Y_{f t} d f$, where $P_{f t}$ is the price of firm $f$ output. The final consumers problem is to minimize the cost subject to the firms production. The solution yields $Y_{f t}=\left(\frac{P_{f t}}{P_{H, t}}\right)^{-\varepsilon} Y_{t}$, where the final goods price 
level is $P_{H, t}=\left[\int_{0}^{1} P_{f t}^{1-\varepsilon} d f\right]^{\frac{1}{1-\varepsilon}}$.

Nominal price rigidity is added to the model in the price of final goods. Each period, firms have a constant probability $(1-\gamma)$ of freely adjusting their price to an optimal level $P_{t}^{o}$ and a probability $\gamma$ of passively realigning its price using a lagged inflation rate. Hence, final prices evolve according to

$$
P_{H, t}=\left[(1-\gamma)\left(P_{t}^{O}\right)^{1-\varepsilon}+\gamma\left(\pi_{H, t-1}^{\gamma_{P}} P_{H, t-1}\right)^{1-\varepsilon}\right]^{\frac{1}{1-\varepsilon}},
$$

where $\pi_{H, t} \equiv \frac{P_{H, t}}{P_{H, t-1}}$ is the gross domestic inflation rate and $\gamma_{P}$ is the measure of price indexation. Dividing equation (18) by $P_{H, t-1}$ and defining $\pi_{t}^{o} \equiv \frac{P_{t}^{o}}{P_{H, t-1}}$ as an optimal price correction factor, the following relation emerges:

$$
\pi_{H, t}^{1-\varepsilon}=(1-\gamma)\left(\pi_{t}^{o}\right)^{1-\varepsilon}+\gamma \pi_{H, t-1}^{\gamma_{P}(1-\varepsilon)} .
$$

Because of nominal price rigidity, the firm's problem is to choose an optimal price, $P_{t}^{o}$, which is the same chosen by other firms that are able to realign price in time $t$, in order to maximize the expected discounted value of profit subject to the result of cost minimization by the final consumers:

$$
\max E_{t} \sum_{i=0}^{\infty} \gamma^{i} \beta^{i} \Lambda_{t, t+i}\left[\frac{P_{t}^{o}}{P_{H, t+i}} \prod_{k=1}^{i}(\pi H, t+k-1)^{\gamma}{ }^{\gamma}-P_{m t+i}\right] Y_{f t+i}, \quad \text { s.a. } Y_{f t+i}=\left(\frac{P_{f t+i}}{P_{H, t+i}}\right)^{-\varepsilon} Y_{t+i},
$$

remembering that because of price realignment to $P_{t}^{o}$, firm $f$ price at time $t+i$ is:

$$
P_{f t+i}=P_{t}^{o} \prod_{k=1}^{i}\left(\pi_{H, t+k-1}\right)^{\gamma_{p}}=P_{t}^{o} \prod_{k=1}^{i}\left(\frac{P_{H, t-1+k}}{P_{H, t-2+k}}\right)^{\gamma_{P}}=P_{t}^{o}\left(\frac{P_{H, t+i-1}}{P_{H, t-1}}\right)^{\gamma_{P}} .
$$

The FOC of this problem is:

$$
\pi_{t}^{o}=\frac{\varepsilon}{\varepsilon-1} \frac{N N_{t}}{D D_{t}} \pi_{H, t}
$$

where:

$$
N N_{t}=Y_{t} P_{m t}+E_{t}\left[\gamma \beta \Lambda_{t, t+1}\left(\frac{\pi_{H, t+1}}{\pi_{H, t}^{\gamma_{P}}}\right)^{\varepsilon} N N_{t+1}\right]
$$

and

$$
D D_{t}=Y_{t}+E_{t}\left[\gamma \beta \Lambda_{t, t+1}\left(\frac{\pi_{H, t+1}}{\pi_{H, t}^{\gamma P}}\right)^{\varepsilon-1} D D_{t+1}\right]
$$

\subsection{Financial intermediaries}

Reserve requirements are introduced in the model with bankers as financial intermediaries between households (lenders) and non-financial firms (borrowers). There 
is an obligation for bankers to keep a fraction of their assets deposited with the monetary authority. A banker has a probability $\theta$ to stay a banker next period, and a probability $(1-\theta)$ to become a worker and take all the gains with him. Assuming that the proportion between bankers and workers is constant, the same quantity of workers become bankers, receiving funds from households in order to start business. Both financial flows are included as lump sum transfers in the household's budget constraint.

The balance sheet of each financial intermediary is

$$
Q_{t} S_{j t}+\tau_{t} B_{j t+1}=N_{j t}+B_{j t+1}
$$

where $S_{j t}$ is the amount of loans that banker $j$ holds, $N_{j t}$ is the amount of net worth at the end of period $t, B_{j t+1}$ is the deposits from households in $t$ with maturity in $t+1$, and $\tau_{t}$ is the rate of reserve requirements over deposits in $t$. Reserve requirements follow Divino and Kornelius (2015), where the monetary authority establishes an obligation for financial intermediates to keep a time-varying fraction of the household's deposits as reserve requirements with the central bank.

Banker $j$ equity capital evolves according to the difference between interests on assets and liabilities, yielding

$$
N_{j t+1}=R_{k t+1} Q_{t} S_{j t}+R_{R R t+1} \tau_{t} B_{j t+1}-R_{t+1} B_{j t+1},
$$

where $R_{R R t}$ is the fraction of market interest rate paid by the monetary authority on the reserve requirements. Using the previous equation, $B_{j t+1}$ might be cancelled out and

$$
N_{j t+1}=\left(R_{k t+1}-R_{\tau t+1}\right) Q_{t} S_{j t}+R_{\tau t+1} N_{j t},
$$

in which the cost of deposits, including reserve requirements, is

$$
R_{\tau t+1} \equiv \frac{R_{t+1}-\tau_{t} R_{R R t+1}}{1-\tau_{t}}=R_{t+1}+\frac{\tau_{t}}{1-\tau_{t}}\left(R_{t+1}-R_{R R t+1}\right)
$$

Taking into account the probability that the banker will remain a banker for $i$ periods, the expected terminal wealth is

$$
V_{j t}=E_{t} \sum_{i=0}^{\infty}(1-\theta) \theta^{i} \beta^{i+1} \Lambda_{t, t+1+i}\left(N_{j t+1+i}\right)
$$

Considering the definition of $N_{j t}$, the sum might be split in two terms, one related to deposits and the other to equity capital, allowing for a solution by using recursive substitution as:

$$
V_{j t}=\nu_{t} Q_{t} S_{j t}+\eta_{t} N_{j t}
$$


where $\nu_{t}$ and $\eta_{t}$ are shadow prices of assets and equity capital, defined as:

$$
\nu_{t} \equiv E_{t}\left[(1-\theta) \beta \Lambda_{t, t+1}\left(R_{k t+1}-R_{\tau t+1}\right)+\theta \beta \Lambda_{t, t+1} x_{t, t+1} \nu_{t+1}\right]
$$

and

$$
\eta_{t} \equiv E_{t}\left[(1-\theta) \beta \Lambda_{t, t+1} R_{\tau t+1}+\theta \beta \Lambda_{t, t+1} z_{t, t+1} \eta_{t+1}\right],
$$

with $x_{t, t+i} \equiv \frac{Q_{t+i} S_{j t+i}}{Q_{t} S_{j t}}$ is the gross growth rate of assets between $t$ e $t+i$ and $z_{t, t+i} \equiv$ $\frac{N_{j t+i}}{N_{j t}}$ is the gross growth rate of net worth between $t$ and $t+i$.

Gertler and Karadi (2011) incorporated a financial friction that prevents financial intermediaries from expanding their assets indefinitely. The banker, at the end of each period, might choose to divert a fraction $\lambda$ of available funds to his/her household. Hence, lenders are willing to supply funds to the financial intermediaries as long as the diverted funds don't surpass the expected terminal wealth. That is, the banker has enough assets to repay all lenders, so that the constraint $V_{j t} \geq \lambda Q_{t} S_{j t}$ must be satisfied.

In case of positive spreads, financial intermediaries are supposed to obtain deposits from households until the constraint binds in order to optimize the expected value of equity capital. Hence, since the constraint binds, we might derive the financial intermediary $j$ 's demand for assets $Q_{t} S_{j t}=\phi_{t} N_{j t}$, where $\phi_{t}$ is the maximum leverage ratio for bankers in $t$ :

$$
\phi_{t} \equiv \frac{\eta_{t}}{\lambda-\nu_{t}} .
$$

The aggregate demand for assets is:

$$
Q_{t} S_{t}=\phi_{t} N_{t}
$$

Replacing $Q_{t+i} S_{j t+i}$ of equation (27) in the definition of $x_{t, t+1}$ yields the relation between the gross growth rates of assets and equity capital:

$$
x_{t, t+1}=\frac{\phi_{t+1}}{\phi_{t}} z_{t, t+1} .
$$

Demand for assets $Q_{t} S_{j t}$ might also be replaced in the evolution of banker $j$ 's net worth, which produces:

$$
N_{j t+1}=\left[\left(R_{k t+1}-R_{\tau t+1}\right) \phi_{t}+R_{\tau t+1}\right] N_{j t}
$$

Since $N_{j t+1}$ is the numerator of $z_{t, t+1}$, the following relation between rates of equity capital growth, return on assets, and interest on liabilities might be derived:

$$
z_{t, t+1}=\left(R_{k t+1}-R_{\tau t+1}\right) \phi_{t}+R_{\tau t+1} .
$$


In order to obtain an equation for aggregate net worth, $N_{t}$, first consider it as $N_{e t}+N_{n t}$, where $N_{e t}$ is the fraction of existing bankers and $N_{n t}$ is the fraction of new ones. For $N_{e t}$, it is assumed a continuum of unit mass of intermediaries $N_{e t}=\int_{0}^{1} N_{e j t} d j$. Hence, the aggregate is

$$
N_{e t}=\int_{0}^{1} N_{e j t} d j=\int_{0}^{1}\left[\left(R_{k t}-R_{\tau t}\right) \phi_{t}+R_{\tau t}\right] N_{e j t-1} d j,
$$

where $N_{e j t}$ is the equity capital of intermediary $j$ at time $t$. Considering that

$$
\int_{0}^{1} N_{e j t-1} d j=N_{e t-1}=\theta N_{t-1}
$$

and using equation (29), we obtain

$$
N_{e t}=\theta z_{t-1, t} N_{t-1}
$$

For $N_{n t}$, it is assumed that households transfer a fraction $\frac{\omega}{(1-\theta)}$ of exiting bankers' assets, net of reserve requirements, as funds to new bankers. The assets of exiting bankers is $(1-\theta) Q_{t} S_{t-1}$, which yields $N_{n t}=\omega Q_{t} S_{t-1}$, where $\omega$ is a parameter of the fraction. The outcome is the law of motion for $N_{t}$ :

$$
N_{t}=\theta z_{t-1, t} N_{t-1}+\omega Q_{t} S_{t-1} .
$$

Lastly, it is worth noticing that although there is no friction in the intermediate goods firms' borrowing, the friction in bankers' funding might affect the availability of lending for non-financial firms, and therefore, the return on capital the firms have to pay.

\subsection{Monetary authority and rest of the world economy}

The monetary authority might obligate financial intermediaries to maintain reserve requirements, deciding the level and the remuneration of this reserve. We consider two alternative rules for the reserve requirements $\tau_{t}$ over total deposits, represented by a fixed rate and a countercyclical rule as follows:

$$
\tau_{t}=\left\{\begin{array}{l}
\text { fixed: } \bar{\tau} \\
\text { countercyclical: } \bar{\tau}+\kappa_{\tau}\left(\log Q_{t} S_{t}-\log Q S s s\right)
\end{array},\right.
$$

where $\bar{\tau}$ is a fixed rate, $\kappa_{\tau}$ is the weight placed by the monetary authority on the credit gap, with $\kappa_{\tau}>0$ and $Q S_{s s}$ being the steady-state level of credit. The parameters are calibrated in order to keep $\tau_{t}$ within the interval $(0,1)$. The remuneration, $R_{R R t}$, 
whenever paid by monetary authority over reserve requirements is specified as a fraction of $R_{t}$ :

$$
R_{R R t+1}=1+\kappa_{R R}\left(R_{t+1}-1\right),
$$

where $\kappa_{R R}$ is the fraction of the market rate. The Fisher equation links nominal and real interest rates:

$$
1+i_{t}=R_{t+1} E_{t} \pi_{t+1}
$$

Assuming no arbitrage in international financial markets and that the ROW has the same preferences as the SOE, a real version of the uncovered interest rate parity (UIP) might be derived. Equations (3) and (5) might be combined to produce: $E_{t}\left[\beta \Lambda_{t, t+1} R_{t+1}\right]=E_{t}\left[\beta \Lambda_{t, t+1} \frac{\epsilon_{t+1}}{\epsilon_{t}} R_{t+1}^{*}\right]$. Substituting domestic and foreign real interest rates for nominal interest rates and inflations according to the Fisher equation (33) and assuming that $\frac{\Lambda_{t, t+1}}{\pi_{t+1}}$ and $\frac{\Lambda_{t, t+1} \epsilon_{t+1}}{\pi_{t+1}^{*}}$ have log-normal distributions, the real version of UIP arises:

$$
q_{t}-E_{t} q_{t+1}=\left(i_{t}^{*}-E_{t} \log \pi_{t+1}^{*}\right)-\left(i_{t}-E_{t} \log \pi_{t+1}\right)+\sigma_{t}
$$

where $q_{t}$ is the logarithm of the real exchange rate and $\sigma_{t}$ is the risk premium.

Imported goods from the ROW alter the price index. Following Gali (2008), consumer price index $(\mathrm{CPI})$ is defined as $P_{t} \equiv\left[(1-\alpha) P_{H, t}^{1-\eta}+\alpha P_{F, t}^{1-\eta}\right]^{\frac{1}{1-\eta}}$, where $P_{H, t}$ is the domestic price index of domestically produced goods - or producer price index (PPI) - and $P_{F, t}$ is the domestic price index of foreign produced goods. Assuming that local and foreign goods are perfect substitutes in steady state and the law of one price holds, one might derive a log-linear equation that relates CPI inflation $\pi_{t}$ and PPI inflation $\pi_{H, t}$ as:

$$
\log \pi_{t}=\log \pi_{H, t}+\frac{\alpha}{1-\alpha} \Delta q_{t}
$$

It is assumed that the monetary authority follows a flexible Taylor rule with interest rate smoothing, choosing either PPI or CPI inflation as targeting rate and reacting or not to exchange rate movements. In this context, four possible configurations arise:

$$
i_{t}=\left\{\begin{array}{l}
\left(1-\rho_{i}\right)\left[i s s+\kappa \pi \log \pi_{H, t}+\kappa y\left(\log Y_{t}-\log Y_{t}^{n}\right)\right]+\rho_{i} i_{t-1}+\varepsilon_{t} \\
\left(1-\rho_{i}\right)\left[i s s+\kappa \pi \log \pi_{, t}+\kappa y\left(\log Y_{t}-\log Y_{t}^{n}\right)+\kappa q q_{t}\right]+\rho_{i} i_{t-1}+\varepsilon_{t} \\
\left(1-\rho_{i}\right)\left[i_{s s}+\kappa \pi \log \pi_{t}+\kappa y\left(\log Y_{t}-\log Y_{t}^{n}\right)\right]+\rho_{i} i_{t-1}+\varepsilon_{t} \\
\left(1-\rho_{i}\right)\left[i_{s s}+\kappa \pi \log \pi_{t}+\kappa y\left(\log Y_{t}-\log Y_{t}^{n}\right)+\kappa_{q} q_{t}\right]+\rho_{i} i_{t-1}+\varepsilon_{t}
\end{array}\right.
$$

where $\rho_{i}$ is a smoothing parameter (with $0<\rho_{i}<1$ ), iss is the steady-state nominal interest rate, $Y_{t}^{n}$ is the natural level of output (under flexible price equilibrium), 
$\kappa \pi, \kappa y$, and $\kappa_{q}$ measure the reaction of the nominal interest rate to inflation, output gap, and exchange rate movements, respectively, and $\varepsilon_{i t} \sim i i d\left(0, \sigma_{i}^{2}\right)$ is an exogenous monetary policy shock. Notice that the closed economy Taylor rule is a particular case of the previous rules, with $\kappa_{q}=0$ and $\pi_{H, t}=\pi_{t}$ when $\alpha=0$.

The choice of the measure of inflation (CPI or PPI) and the inclusion or not of the exchange rate allows to investigate which interest rate rule presents the best performance to stabilize the economy against alternative exogenous shocks. Then, the chosen interest rate rule is confronted with alternative reserve requirements rules order to identify the combination which yields the highest welfare for the economy.

To close the model and without loss of generality, it is assumed that the foreign interest rate, foreign inflation rate, and risk premium all follow stationary $\operatorname{AR}(1)$ processes given by:

$$
\begin{gathered}
i_{t}^{*}=\rho_{i *} i_{t-1}^{*}+\varepsilon_{i * t}, \\
\log \pi_{t}^{*}=\rho_{\pi *} \log \pi_{t-1}^{*}+\varepsilon_{\pi * t},
\end{gathered}
$$

and

$$
\sigma_{t}=\left(1-\rho_{\sigma}\right) \sigma_{s s}+\rho_{\sigma} \sigma_{t-1}+\varepsilon_{\sigma t},
$$

where $\sigma_{s s}$ is the steady-state risk premium, $\rho_{i *} \in(0,1), \rho_{\pi *} \in(0,1), \rho_{\sigma} \in(0,1), \varepsilon_{i * t} \sim$ $i i d\left(0, \sigma_{i * t}^{2}\right), \varepsilon_{\pi * t} \sim i i d\left(0, \sigma_{\pi * t}^{2}\right)$, and $\varepsilon_{\sigma t} \sim i i d\left(0, \sigma_{\sigma t}^{2}\right)$.

\subsection{Equilibrium}

Output is divided into consumption and investment, which includes adjustment cost, according to the economy-wide resource constraint:

$$
Y_{t}=C_{t}+I_{t}+\frac{\eta_{i}}{2}\left(\frac{I_{n t}+I_{s s}}{I_{n t-1}+I_{s s}}-1\right)^{2}\left(I_{n t}+I_{s s}\right) .
$$

Labour market clearing implies that labour supply should be equal to labour demand. Hence, the same wage $w_{t}$ is earned by workers and paid by firms. Combining (1) and (12) yields:

$$
\frac{\chi L_{t}^{\varphi}}{U M g C_{t}}=P_{m t}\left(1-\alpha_{c}\right) \frac{Y_{m t}}{L_{t}} .
$$

Goods market clearing requires that intermediate and final goods production are adjusted by a price dispersion $D_{t}$ given by:

$$
Y_{m t}=D_{t} Y_{t}
$$


where:

$$
D_{t}=\gamma D_{t-1}\left(\frac{\pi_{H, t}}{\pi_{H, t-1}^{\gamma p}}\right)^{\varepsilon}+(1-\gamma)\left(\frac{1-\gamma\left(\frac{\pi_{H, t}}{\pi_{H, t-1}^{\gamma p}}\right)^{\gamma-1}}{1-\gamma}\right)^{\frac{-\varepsilon}{1-\gamma}}
$$

Total deposits by domestic households, $B_{t}$, are equal to the sum of the deposits received by each one of the $j$ financial intermediaries, $B_{j t}$. The aggregate balance sheet of the financial intermediaries is $Q_{t} S_{t}+\tau_{t} B_{t+1}=N_{t}+B_{t+1}$. Rearranging this equation and using (27), we might express $B_{t+1}$ as:

$$
B_{t+1}=\frac{1}{1-\tau_{t}}\left(\phi_{t}-1\right) N_{t}
$$

All financial claims held by financial intermediaries are used to finance acquisition of capital by intermediate goods firms, which is implicitly expressed in equation (6).

\section{$3 \quad$ Results}

The model is calibrated for the Brazilian economy in order to simulate the dynamics of the economy after exogenous shocks in domestic monetary policy, productivity, and foreign monetary policy. Initially, we investigate which measure of inflation, represented by either CPI or PPI, should enter the interest rate rule, and whether this rule should respond to the exchange rate. Then, we confront this policy with alternative rules for reserve requirements on the side of the macroprudential policy. We evaluate the performance of these policy rules to stabilize the economy and perform a welfare analysis.

\subsection{Calibration}

The values of the parameters used in the simulations are, for the most part, equivalent to those commonly found in the literature. Most of the parameter values were also used by Divino and Kornelius (2015), Gertler and Karadi (2011) and Castro et al. (2015). Table 1 displays the calibrated values along with the respective sources.

The values of $\delta_{a}$ and $\delta_{b}$ are calibrated according to the functional form of the depreciation rate $\delta\left(U_{t}\right)$ so that the steady-state values of the depreciation rate, $\delta$, and the rate of capital utilization, $U$, are equal to 0.025 and 1 , respectively. The fraction of capital transferred to new bankers, $\omega$, is calibrated to allow for the ratio of equity to loans to be $\frac{1}{\phi}=0.175$, which is close to the Brazilian data. The reserve requirement, $\bar{\tau}$, the coefficient of credit gap in the countercyclical macroprudential rule, $\kappa_{\tau}$, and the fraction of market rate paid by the monetary authority on reserve 
Table 1: Parameters values

\begin{tabular}{|c|c|c|c|}
\hline Par. & Value & Description & Source \\
\hline \multicolumn{4}{|c|}{ Households } \\
\hline$\beta$ & 0.989 & Intertemporal discount factor & Castro et al. (2015) \\
\hline$h$ & 0.74 & Consumption habit persistence & Castro et al. (2015) \\
\hline$\chi$ & 3.409 & Labor weight in the utility function & Gertler and Karadi (2011) \\
\hline$\phi$ & 0.276 & Inverse of the Frisch Labor-supply elasticity & Gertler and Karadi (2011) \\
\hline \multicolumn{4}{|c|}{ Intermediate goods firms } \\
\hline$\alpha_{c}$ & 0.33 & Capital share in the production function & Divino and Kornelius (2015) \\
\hline$\delta_{a}$ & 0.02039 & 2 Depreciation rate & Calibrated by the authors \\
\hline$\delta_{b}$ & 0.03778 & $\begin{array}{l}7 \text { Slope of the depreciation rate in relation to the } \\
\text { capital utilization rate }\end{array}$ & Calibrated by the authors \\
\hline$\zeta$ & 7.2 & Capital utilization rate & Gertler and Karadi (2011) \\
\hline \multicolumn{4}{|c|}{ Capital goods firms } \\
\hline$I_{s s}$ & \multicolumn{2}{|c|}{0.112175 Steady-state investment } & Calculated by the authors \\
\hline$\eta_{i}$ & 3.42 & $\begin{array}{l}\text { Inverse of the investment elasticity in relation to } \\
\text { the capital price }\end{array}$ & Gertler and Karadi (2011) \\
\hline \multicolumn{4}{|c|}{ Final goods firms } \\
\hline$\varepsilon$ & 4.1667 & Constant elasticity of substitution & Gertler and Karadi (2011) \\
\hline$\gamma$ & 0.74 & Calvo probability of not changing prices & Castro et al. (2015) \\
\hline$\gamma_{P}$ & 0.33 & Inflation decay factor & Castro et al. (2015) \\
\hline \multicolumn{4}{|c|}{ Financial intermediates } \\
\hline$\theta$ & 0.975 & Banker survival probability & Divino and Kornelius (2015) \\
\hline $\bar{\lambda}$ & 0.28 & $\begin{array}{l}\text { Fraction of available funds that the banker diverts } \\
\text { to his family }\end{array}$ & Divino and Kornelius (2015) \\
\hline$\omega$ & 0.00087 & 5 Fraction transferred to the new bankers & Divino and Kornelius (2015) \\
\hline \multicolumn{4}{|c|}{ Monetay autority and aggregate restrictions } \\
\hline$i_{s s}$ & 0.01112 & 2 Nominal interest rate in steady state & Calculated by the authors \\
\hline$Q S_{s s}$ & 4.48700 & 4 Credit level in steady state & Calculated by the authors \\
\hline$\kappa_{\pi}$ & 2.43 & Inflation coefficient in the Taylor rule & Castro et al. (2015) \\
\hline$\kappa_{y}$ & 0.16 & Output gap coefficient in the Taylor rule & Castro et al. (2015) \\
\hline$\kappa_{q}$ & 0.4762 & Real exchange rate coefficient in the Taylor rule & West (2003) \\
\hline$\rho_{i}$ & 0.79 & Interest rate smoothing in the Taylor rule & Castro et al. (2015) \\
\hline $\bar{\tau}$ & 0.45 & Fixed level of reserve requirements & Divino and Kornelius (2015) \\
\hline$\kappa_{\tau}$ & 0 & $\begin{array}{l}\text { Credit gap coefficient in the reserve requirements } \\
\text { rule }\end{array}$ & Divino and Kornelius (2015) \\
\hline$\kappa_{R R}$ & 0 & $\begin{array}{l}\text { Fraction of the market interest rate paid over re- } \\
\text { serve requirements }\end{array}$ & Divino and Kornelius (2015) \\
\hline \multicolumn{4}{|c|}{ Rest of the world } \\
\hline$\alpha$ & 0.12 & Degree of openness & Calculated by the authors \\
\hline$\sigma_{s s}$ & 0.01112 & 2 Risk premium in steady state & Calculated by the authors \\
\hline
\end{tabular}

requirement, $\kappa_{R R}$, are calibrated according to the data for the Brazilian economy. For other parameters, we use the values estimated by Castro et al. (2015) for the Brazilian economy. When this is not possible, we choose the same values set by Gertler and Karadi (2011).

For the parameter $\alpha$, which measures the degree of openness of the economy, we found values of 0.25 in (Glocker and Towbin, 2012), 0.3 in (Divino, 2009a), and 0.4 in (Araújo, 2016; Gali and Monacelli, 2005). However, these studies refer to developed countries where the degree of openness is greater than that of Brazil. Thus, we approximate this parameter by the average value in the last 10 years of the ratio of imports to GDP in the Brazilian economy, which is 0.12 according to 
the data from the Brazilian Institute of Geography and Statistics (IBGE).

The coefficient of real exchange rate in the interest rate rule varies according to the exchange rate regime. We include the real exchange rate in the policy rule as alternative to simulate a dirty floating exchange rate regime ${ }^{6}$. Araújo (2016) used a value of 0.6 , but on the relative variation of the nominal exchange rate. For the relative variation of the real exchange rate, Ferreira (2015) estimates a value close to 0.47 for the Brazilian economy. West (2003) used a coefficient lower than 0.1, which is consistent with the fact that it is applied only on the contemporaneous value of the log real exchange rate. Thus, we also decide to use 0.1 for this parameter along with an interest rate smoothing of 0.79 .

The list of parameters is completed by the steady-state values of total investment, $I_{s s}$, domestic nominal interest rate, $i_{s s}$, credit level, $Q_{s s} S_{s s}$, and risk premium, $\sigma_{s s}$. These values were calculated along with the other endogenous variables in the steady state.

For the experiments performed ahead, we apply persistences and shocks as reported in Table 2. Foreign inflation rate $\left(\pi^{*}\right)$ and risk premium $(\sigma)$ are modelled as stationary $\mathrm{AR}(1)$ processes. However, they are kept inactive in the simulations as we only consider shocks in domestic monetary policy, productivity, and foreign monetary policy.

Table 2: Calibration of the exogenous shocks

\begin{tabular}{clll}
\hline Par. & Value & Description & Source \\
\hline$\rho_{A}$ & 0.95 & Persistency of technology shock & Gertler and Karadi (2011) \\
$\rho_{i}$ & 0.90 & Persistency of domestic interest rate shock & Castro et al. (2015) \\
$\rho_{i *}$ & 0.90 & Persistency of foreign interest rate shock & Castro et al. (2015) \\
$\rho_{\pi *}$ & 0.13 & Persistency of foreign inflation rate shock & Castro et al. (2015) \\
$\rho_{\sigma}$ & 0.73 & Persistency of risk premium shock & Castro et al. (2015) \\
$\varepsilon_{A}$ & 0.01 & Shock in technology & Gertler and Karadi (2011) \\
$\varepsilon_{i}$ & 0.0025 & Shock in domestic interest rate & Castro et al. (2015) \\
$\varepsilon_{i *}$ & 0.0025 & Shock in foreign interest rate & Castro et al. (2015) \\
\hline
\end{tabular}

\subsection{Impulse Response Functions}

We applied an exogenous shock in the domestic monetary policy, $\varepsilon_{i}$, given by an unexpected increase of 0.25 percentage point $(\mathrm{pp})$ in the nominal interest rate. Figure 7, reported in the Appendix, illustrates the dynamics of the economy after this shock with either $\pi_{H}$ or $\pi$ in the rule for the domestic interest rate. Basically, there is no significant difference in the behaviour of the variables between these two specifications and a closed economy due to the fact that the rest of the world

\footnotetext{
${ }^{6}$ Other forms of dirty floating exchange rate include direct and indirect interventions in the currency market.
} 
economy is completely exogenous to the small open economy and the degree of openness is too low $(\alpha=0.12)$. In this scenario, domestic shocks do not affect foreign variables and changes in the real exchange rate only marginally affect CPI inflation, $\pi$, according to equation (34). The openness of the economy does not play any relevant role on the dynamics of the variables. This result replicates some of the findings by (Gali and Monacelli, 2005), but in a richer environment.

A similar analysis applies to the productivity shock, represented by a $1 \%$ increase in the total factor productivity, $A_{t}$. Figure 8 in the Appendix reports the results using either $\pi_{H}$ or $\pi$ in the interest rate rule. As for the previous shock, the endogenous variables evolved as expected, but the openness of the economy does not yield any significant differences in the dynamics of the variables. The productivity shock lead to an increase in output and a decrease in inflation, which decreases the nominal interest rate and depreciates the real exchange rate. Again, the inclusion of either $\pi$ or $\pi_{H}$ in the interest rate rule does not differentiate the dynamics of the small open and a closed economy.

The environment, however, is quite different when the exogenous shock has a foreign source. This shock is represented by an unexpected increase of $0.25 p p$ in the foreign nominal interest rate, which is the monetary policy instrument of the world economy. Figure 1 illustrates the trajectories of the impulse-responses in a horizon of 20 quarters, incorporating either $\pi_{H}$ or $\pi$ in the domestic interest rate rule.

The increase of the foreign interest rate encourages the purchase of foreign securities by the domestic households, increasing the demand for foreign currency and reducing the volume of domestic deposits. The higher demand for foreign currency depreciates the home currency, making imported goods more expensive and causing a momentary increase in $\pi$. There is a reduction in $\pi_{H}$ because of the decrease in labour, which reduces the firm's marginal cost and dominates the effects of the higher $\pi$ on $\pi_{H}$ through the wage inflation. The monetary policy reacts by rising the nominal interest rate above the increase in inflation according to the Taylor principle. As a consequence, the domestic real interest rate increases and induces falls in output, consumption, investment, capital, labour, and credit. The real exchange rate, $q$, gradually moves down towards equilibrium, leading the convergence of the other variables to the steady state.

The dynamics of the variables are sharply affected by the presence of $\pi$ instead of $\pi_{H}$ in the interest rate rule. This result is quite different from those obtained for the domestic shocks, which did not yield significant differences in the dynamics of the domestic variables when compared to a closed economy. The CPI inflation rate, $\pi$, is strongly impacted by the foreign shock through the real exchange rate depreciation. The jump in CPI inflation presses both the nominal interest rate, 
Figure 1: Responses to a shock in the foreign monetary policy

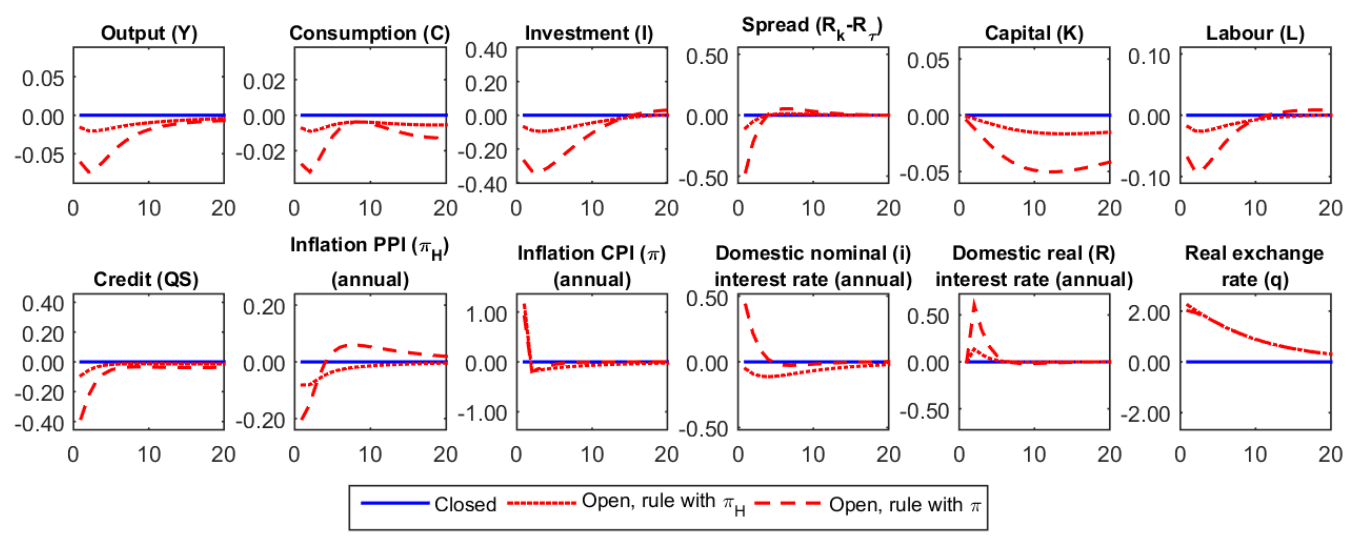

through the Taylor rule, and the real interest rate, through the Fisher equation, which in turn reinforces the effects on the real side of the economy. Using $\pi$ instead of $\pi_{H}$ in the interest rate rule contributes to import the external volatility to the domestic variables. This does not happen when the interest rate rule targets $\pi_{H}$ as measure of inflation. Thus, under a shock in foreign variables, it is advisable for the monetary policy to target domestic inflation in the interest rate rule.

\subsection{Alternative interest rate rules}

In order to analyse the performance of alternative interest rate rules to stabilize the small open economy, we consider the effects of shocks in the domestic monetary policy under four different configurations, combining two measures of inflation $(\pi$ or $\left.\pi_{H}\right)$ and including or not the real exchange rate $(q)$ in the monetary policy reaction function. To compare them, we apply shocks of different magnitudes in the nominal interest rate seeking to generate the same decrease of $0.39 \mathrm{pp}$ per year in $\pi_{H}$ in the first quarter. This decrease corresponds to a raise of $0.25 \mathrm{pp}$ in the nominal interest rate under a policy rule that targets $\pi_{H}$ and does not react to the real exchange rate, $q$.

Figure 2 indicates that there are no significant differences in the dynamics of the variables across the interest rate rules, except for the fact that a higher increase of $0.34 \mathrm{pp}$ in the nominal interest rate is required to produce the same decrease of 0.39pp in $\pi_{H}$ when the policy rules include the real exchange rate, $q$. As explained previously, this is because the rest of the world economy is not affected by the domestic shock and the degree of openness of the small open economy is low. The first row of responses in Figure 2 presents interest rate rules that target $\pi_{H}$ while the second row shows rules that react to $\pi$. In either case, it is a better choice for the 
monetary policy not to directly respond to exchange rate movements in the interest rate rule.

Figure 2: Responses of selected variables to a shock in the domestic monetary policy
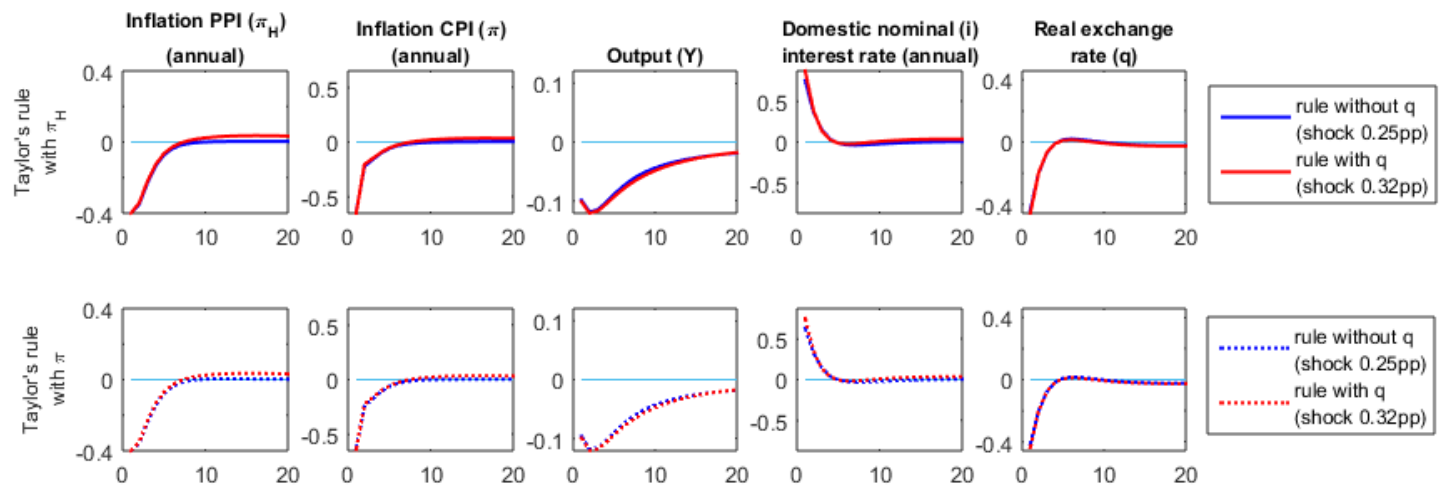

In an environment of a foreign shock, as illustrated in Figure 3, the results are different. Policy rules that target PPI inflation $\left(\pi_{H}\right)$ instead of CPI inflation $(\pi)$ are more successful to stabilize output and interest rate. The inclusion of $q$ in these rules, however, substantially amplifies the series volatility. The responses are higher on impact and more persistent than in the configurations that do not include $q$ in the interest rate rules. Only the real exchange rate seems to benefit because the effects of the shock on impact are smaller. This finding suggests stabilization of the real exchange rate might be achieved at a cost of higher instability for other domestic variables. Considering rules without $q$, the monetary authority is better off by targeting PPI instead of CPI inflation, which amplifies volatility in domestic nominal interest rate and output when entering the policy rule.

Figure 3: Responses of selected variables to a shock in the foreign monetary policy
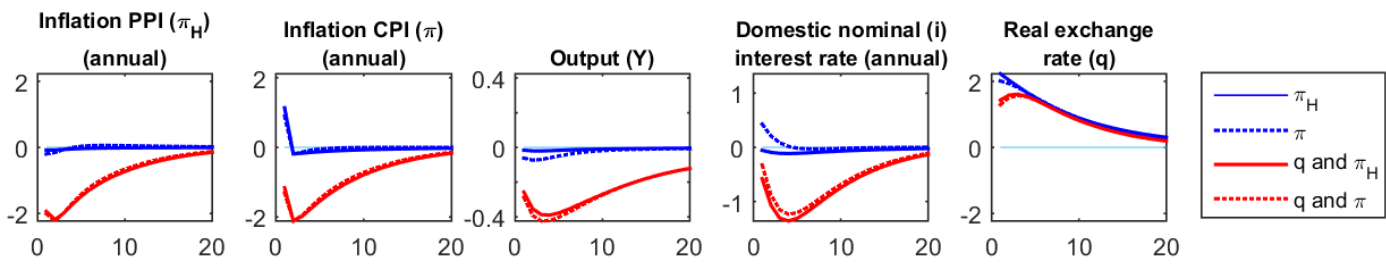

\subsection{Reserve requirements rules}

Following the approach by Agénor et al. (2015) and Divino and Kornelius (2015), we perform simulations considering different rules for reserve requirements and exogenous shocks. Figure 4 reports impulse-responses under alternative values for the parameters $\bar{\tau}$ and $\kappa_{\tau}$ when the small open economy is hit by shocks in the domestic 
monetary policy, total factor productivity, and foreign monetary policy. The shocks still follow the specifications described in Table 2. The nominal interest rate targets $\pi_{H}$ instead of $\pi$ and the real exchange rate does not enter in the policy rule. This specification was identified as the best choice for the monetary policy in the previous section.

Figure 4: Responses under alternative policy rules for reserve requirements
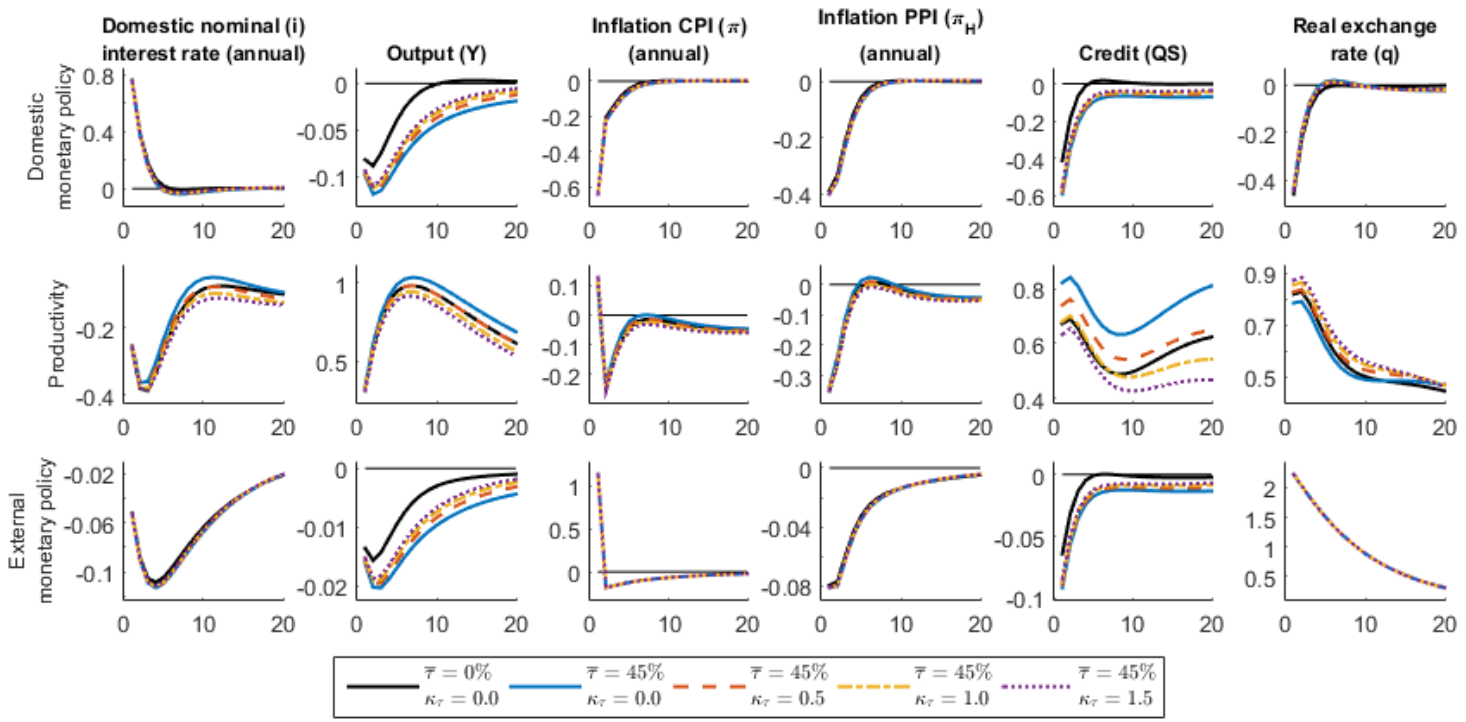

In general, according to Figure 4, in the case where there are no reserve requirements, given by $\bar{\tau}=0$ and $\kappa_{\tau}=0$, the effects of shocks in both domestic and foreign monetary policies are smoother when compared to the other situations where there is an active macroprudential policy. After the introduction of the fixed component of reserve requirements, represented by $\bar{\tau}=0.45$, the deviations of the variables are higher on impact of the shocks. However, the inclusion of the varying component that reacts to the credit gap reduces volatilities and leads to a faster convergence to the steady state. In some cases, the higher the value of the parameter $\kappa \tau$, the faster is the convergence to the equilibrium.

The volatilities reported in Table 3, represented by the series standard deviations, indicate the economy without reserve requirements $\left(\kappa_{\tau}=0\right.$ and $\left.\bar{\tau}=0\right)$ is less volatile in the occurrence of shocks in both domestic and foreign monetary policies. After the inclusion of the varying component in the macroprudential rules, the series volatilities decrease as $\kappa_{\tau}$ increases, suggesting that a more aggressive countercyclical policy to stabilize credit deviations presents a better performance. This is the case for all variables but the nominal interest rate and real exchange rate after a domestic monetary shock and inflation rates after a foreign monetary policy shock.

For the productivity shock, the results are disperse. A fixed rule decreases the volatility of $i, \pi$, and $\pi_{H}$, but increases the volatility of $Y, Q S$, and $q$ when compared 
to the case without a macroprudential policy. The varying component, in its turn, increases the volatility of $i, \pi$, and $\pi_{H}$ and decreases the volatility of $Y, Q S$, and $q$. Thus, taking all variables and exogenous shocks as a whole, for the vast majority, there is an opposite effect on the series volatilities coming from fixed versus flexible rules for reserve requirements. In addition, the macroprudencial policy is more effective to stabilize the small open economy under financial shocks (domestic and foreign monetary policies) than in the case of a real shock (total factor productivity).

Table 3: Volatilities under alternative policy rules for reserve requirements

\begin{tabular}{|c|c|c|c|c|c|c|}
\hline Policy rule & $i$ & $\log (Y)$ & $\log (\pi)$ & $\log \left(\pi_{H}\right)$ & $\log (Q S)$ & $q$ \\
\hline \multicolumn{7}{|c|}{ Shock in the domestic monetary policy $\left(\epsilon_{i}\right)$} \\
\hline $\bar{\tau}=0.0, \kappa_{\tau}=0.0$ & 0.0087 & 0.0016 & 0.0069 & 0.0057 & 0.0046 & 0.0053 \\
\hline $\bar{\tau}=45, \kappa_{\tau}=0.0$ & 0.0086 & 0.0029 & 0.0071 & 0.0060 & 0.0084 & 0.0050 \\
\hline $\bar{\tau}=45, \kappa_{\tau}=0.5$ & 0.0086 & 0.0027 & 0.0071 & 0.0060 & 0.0077 & 0.0050 \\
\hline $\bar{\tau}=45, \kappa_{\tau}=1.0$ & 0.0086 & 0.0025 & 0.0070 & 0.0060 & 0.0073 & 0.0050 \\
\hline $\bar{\tau}=45, \kappa_{\tau}=1.5$ & 0.0086 & 0.0024 & 0.0070 & 0.0059 & 0.0070 & 0.0051 \\
\hline \multicolumn{7}{|c|}{ Productivity shock $\left(\epsilon_{A}\right)$} \\
\hline $\bar{\tau}=0.0, \kappa_{\tau}=0.0$ & 0.0099 & 0.0418 & 0.0041 & 0.0051 & 0.0422 & 0.0315 \\
\hline $\bar{\tau}=45, \kappa_{\tau}=0.0$ & 0.0092 & 0.0462 & 0.0039 & & $0 .($ & 0.0324 \\
\hline $\bar{\tau}=45, \kappa_{\tau}=0.5$ & 0.0099 & 0.0416 & 0.0042 & 0.0050 & 0.0430 & 0.0324 \\
\hline $\bar{\tau}=45, \kappa_{\tau}=1.0$ & 0.0103 & 0.0389 & 0.0044 & 0.0052 & 0.0350 & 0.0324 \\
\hline $\bar{\tau}=45, \kappa_{\tau}=1.5$ & 0.0107 & 0.0371 & 0.0046 & 0.0053 & 0.0298 & 0.0324 \\
\hline \multicolumn{7}{|c|}{ Shock in the foreign monetary policy $\left(\epsilon_{i *}\right)$} \\
\hline $\bar{\tau}=0.0, \kappa_{\tau}=0.0$ & 0.0031 & 0.0003 & 0.0120 & 0.0015 & 0.0007 & 0.0521 \\
\hline $\bar{\tau}=45, \kappa_{\tau}=0.0$ & 0.0032 & 0.0006 & 0.0120 & 0.0015 & 0.0014 & 0.0522 \\
\hline $\bar{\tau}=45, \kappa_{\tau}=0.5$ & 0.0032 & 0.0005 & 0.0120 & 0.0015 & 0.0013 & 0.0522 \\
\hline $\bar{\tau}=45, \kappa_{\tau}=1.0$ & 0.0032 & 0.0005 & 0.0120 & 0.0015 & 0.0012 & 0.0521 \\
\hline $\bar{\tau}=45, \kappa_{\tau}=1.5$ & 0.0031 & 0.0004 & 0.0120 & 0.0015 & 0.0011 & 0.0521 \\
\hline
\end{tabular}

Lastly, to analyse the interaction between the monetary and macroprudential policies, we compare the magnitudes of the shocks required in the nominal interest rate in order to produce the same decrease in inflation under alternative configurations of the macroprudential policy rules. As in the previous section, we seek to generate the same decrease of 0.39pp per year in $\pi_{H}$ in the first quarter. This requires a $0.25 \mathrm{pp}$ increase in the nominal interest rate under no policy rule for reserve requirements $(\kappa \tau=0$ and $\bar{\tau}=0)$. As a fixed rate is introduced $(\bar{\tau}=0.45)$, Figure 3 and Table 2 indicate the required raise in the nominal interest rate reduces to $0.242 \mathrm{pp}$ and the volatilities of $i, \pi$, and $q$ decreases, while the volatilities of $Y, \pi_{H}$, and $Q S$ increases. The required raise in $i$ is still smaller than $0.25 \mathrm{pp}$ when the varying component is included in the policy rules.

The results indicate there might be complementarity between the macroprudential policy and the monetary policy in the small open economy. The increase in the nominal interest rate reduces the credit level, which leads to a decrease in reserve requirements according to the countercyclical macroprudential rule responding to the credit gap. The decrease in credit below the equilibrium level leads to a reduc- 
Figure 5: Responses to domestic monetary policy shocks under the same decrease in $\pi_{H}$

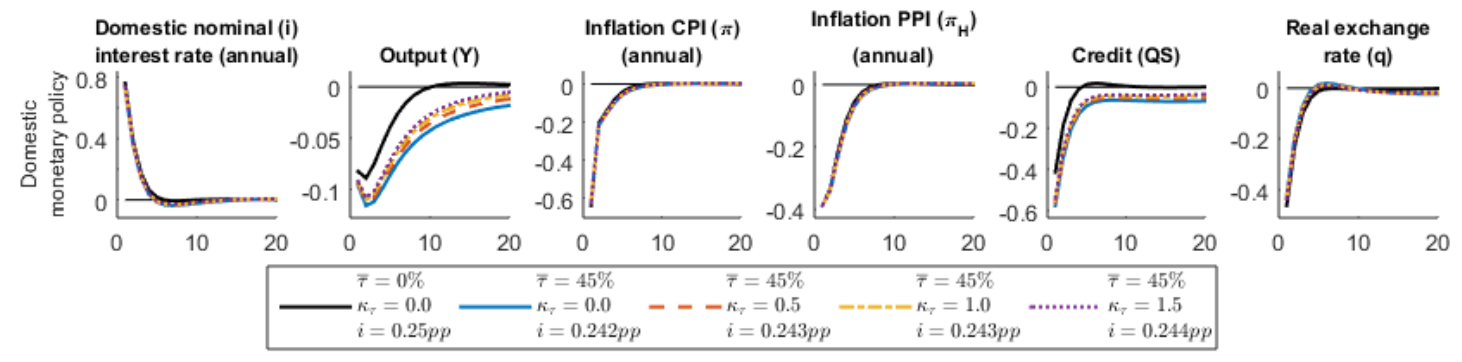

Table 4: Volatilities under domestic monetary policy shocks and the same decrease in $\pi_{H}$

\begin{tabular}{lllllll}
\hline Policy rule & $i$ & $\log (Y)$ & $\log (\pi)$ & $\log \left(\pi_{H}\right)$ & $\log (Q S)$ & $q$ \\
\hline $\bar{\tau}=0.0, \kappa_{\tau}=0.0$ & 0.0087 & 0.0016 & 0.0069 & 0.0057 & 0.0046 & 0.0053 \\
$\bar{\tau}=45, \kappa_{\tau}=0.0$ & 0.0083 & 0.0028 & 0.0068 & 0.0058 & 0.0081 & 0.0048 \\
$\bar{\tau}=45, \kappa_{\tau}=0.5$ & 0.0084 & 0.0026 & 0.0068 & 0.0058 & 0.0075 & 0.0049 \\
$\bar{\tau}=45, \kappa_{\tau}=1.0$ & 0.0084 & 0.0024 & 0.0069 & 0.0058 & 0.0071 & 0.0049 \\
$\bar{\tau}=45, \kappa_{\tau}=1.5$ & 0.0084 & 0.0023 & 0.0069 & 0.0058 & 0.0068 & 0.0049 \\
\hline
\end{tabular}

tion in reserve requirements according to the countercyclical rule given by equation 31. The aggressiveness of the reaction depends on the response parameter $\kappa \tau$. The drop in reserve requirements increases the credit supply to the intermediate goods producing firms, feeding the production of final goods at a lower cost. Thus, the macroprudential policy contributes to reduce the initial impact of the rise in the nominal interest rate on the output gap and to bring the small open economy more quickly to the steady-state equilibrium.

The response of reserve requirements, partially neutralizing the effects of the variation in the nominal interest rate, is in accordance with Areosa and Coelho (2013). However, differently from their experiment, the macroprudential policy in our model is endogenous and interacts with the monetary policy through the credit channel to stabilize the economy. Carvalho and Castro (2015a,b) and Areosa and Coelho (2013) argue that, in isolation, a monetary policy has a stronger impact on GDP and inflation than a macroprudential policy. The inclusion of the endogenous macroprudential policy rule makes reserve requirements respond in opposite direction to the monetary policy, and thus, partially offsets its effects in the economy.

Glocker and Towbin (2015) estimate a Structural VAR for the Brazilian economy and compare the macroeconomic effects of interest rate and reserve requirement shocks. They find that both policies result in credit decline under a discretionary tightening. However, contrary to an interest rate shock, a positive shock in reserve requirements leads to exchange rate depreciation and increase in prices, having the bank lending channel as the main transmission mechanism. They interpret these different effects as evidence that a reserve requirement policy is a complement to rather than a substitute for interest rate policy.

Accordingly, our results indicate the reserve requirement rule that reacts to the 
credit gap contributes to reduce the series volatility and shorten the period to reach the steady state after the domestic interest rate shock. This point is confirmed by the welfare analysis reported in the next section.

\subsection{Welfare analysis}

In order to evaluate the optimal level of reserve requirements, we compute a welfare loss as a function of different values of parameters $\bar{\tau}$ and $\kappa_{\tau}$ in the macroprudential policy rule for reserve requirements. The welfare function, following the literature, is defined from the intertemporal utility function as: ${ }^{7}$

$$
\mathbb{W}_{t}=\sum_{i=t}^{\infty} \beta^{i-t} E_{t}\left[u\left(C_{i}, L_{i}\right)\right]
$$

where $\mathbb{W}_{t}$ represents the welfare measure in period $t$. The welfare loss is given by the negative deviation from the steady-state level. Figure 6 reports results for simulations with $\bar{\tau}$ ranging from 0.0 to 0.45 and $\kappa_{\tau}$ varying from 0.0 to 1.5.

Figure 6: Welfare loss under different configurations for the macroprudential rule

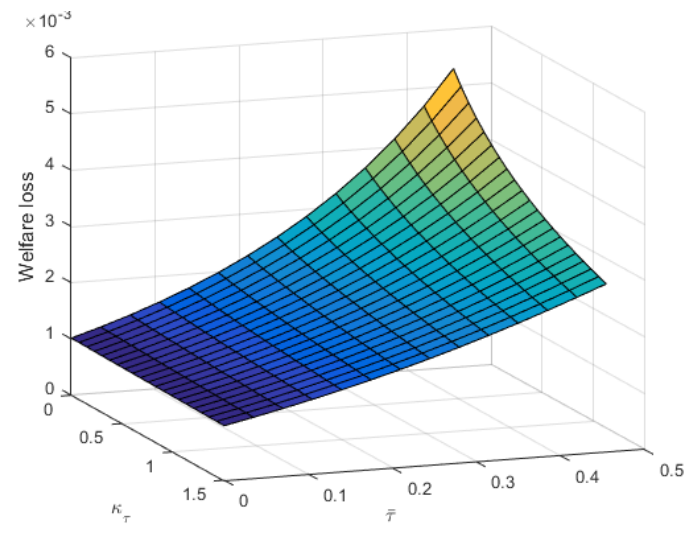

The results suggest the smaller the fixed component $\bar{\tau}$, the lower the welfare loss is. Moreover, given a fixed value for $\bar{\tau}$, a policy rule with a higher response to the credit gap (higher $\kappa_{\tau}$ ) reduces the welfare loss after a shock in the domestic monetary policy. This finding is in line with the previous results. With a higher $\kappa_{\tau}$, the reduction in credit due to the increase in the domestic interest rate is compensated by a decrease in reserve requirements. In this scenario, the countercyclical performance of the macroprudential policy contributes to bring the credit level back to equilibrium more quickly, which positively reflects on the real side of the economy.

\footnotetext{
${ }^{7}$ Woodford (2003) derives a quadratic social loss function, $L_{t}=\left(\log \pi_{t}\right)^{2}+\lambda_{y}\left(\log Y_{t}-\log Y_{t}^{n}\right)^{2}$, from a second order approximation of the utility function in a closed economy without government. We also applied this loss function and the results were very similar to the ones reported in Figure 6 .
} 
The reverse movement is also observed under a reduction in the domestic interest rate, which might drive credit above the steady-state level. In this case, a raise in reserve requirements pulls the economy back to equilibrium faster. Thus, a combination of an interest rate rule that targets domestic inflation and does not respond directly to the exchange rate with a reserve requirement rule that has only a varying component reacting aggressively to the credit gap yields the smallest welfare loss to the small open economy.

Under a wider macroprudential environment, others policy instruments, such as capital requirements (Ferreira and Nakane, 2015), capital regulation in the form of Basel III-type rules (Clancy and Merola, 2017), and central bank loans to nonfinancial firms (Gertler and Karadi, 2011), also yielded smaller welfare losses under more aggressive policy rules. Kiley and Sim (2017), however, warn that countercyclical macroprudential instruments might enhance welfare, but simple-rule approaches must be cautious not to limit credit expansions associated with efficient investment opportunities.

\section{Conclusion}

The objective of this paper was to investigate how a combination of a monetary policy based on interest rate rules and a macroprudential policy of reserve requirements might affect the dynamics of a small open economy with financial frictions. The proposed DSGE model brought together elements of financial frictions, monetary policy, and macroprudential policy in an open economy environment. The model was calibrated for the Brazilian economy. We analysed the effects of exogenous shocks in domestic monetary policy, productivity, and foreign monetary policy and the role of the exchange rate for the transmission of these exogenous shocks to the small open economy. The monetary policy sets rules for the nominal interest rate, while the macroprudential policy establishes reserve requirement rules. A welfare analysis was performed to evaluate the performance of these alternative policy rules.

Under domestic perturbations, represented by monetary policy and productivity shocks, there were no significant differences between the dynamics of a small open economy and a closed economy. This is because the rest of the world economy was exogenous to the small open economy, preventing the transmission of domestic shocks to foreign variables, and the degree of openness was low, as is the case of the Brazilian economy. In the case of foreign monetary policy shock, however, the effects on the domestic variables were more pronounced, leading to a drop in both real and financial sector variables. The impacts were weaker and convergence to the equilibrium was faster when the interest rate rule targeted domestic inflation, as 
opposed to CPI inflation, and did not respond directly to the exchange rate. This configuration of the interest rate rule appeared as the best choice of the monetary policy to stabilize the economy under foreign shocks.

The inclusion of the exchange rate in the interest rate rule reduced the effectiveness of the monetary policy, demanding a higher increase in the nominal interest rate in order to achieve a given decrease in the domestic inflation when compared to the case where the exchange rate did not enter that rule. Under a foreign monetary policy shock, the performance of domestic inflation targeting was also better than the CPI inflation targeting. These results are in line with Divino (2009a), who argued that domestic inflation targeting yields the smallest volatilities for most endogenous variables under a foreign shock, but shows no significant differences in relation to CPI inflation targeting after domestic shocks. The low degree of openness contributes to explain this apparent divergence. But, taken as a whole, the results suggest that domestic inflation targeting is a more appropriate monetary policy regime for the small open economy.

A reserve requirement rule that incorporated an aggressive response to the credit gap contributed to smooth variations in output, credit, inflation, and interest rate in the event of a domestic monetary policy shock. This performance was also observed in the case of a foreign monetary policy shock, with the inclusion of the real exchange rate in the previous set of smoother variables. Under a productivity shock, however, only output, credit, and real exchange rate displayed smoother trajectories. In this case, economic stability was more easily achieved with no macroprudential policy of reserve requirements.

The absence of a fixed rate of reserve requirement was indicated under domestic and foreign shocks because this policy reduced the volatility of most of the domestic variables. In addition, a higher response to credit gap in the reserve requirement rule further reduced volatilities of the variables and led to faster convergence to the steady-state equilibrium after both domestic and foreign monetary policy shocks. The drop in reserve requirements under these shocks increases the credit supply to the intermediate goods producing firms, feeding the production of final goods at a lower cost. The welfare analysis confirmed a combination of an interest rate rule that targets domestic inflation and a reserve requirement rule that reacts more aggressively to the credit gap yielded the smallest welfare loss to the small open economy. This evidence, as in Glocker and Towbin (2015) for the Brazilian economy, highlights the role of the reserve requirement policy as a complement to the traditional monetary policy based on interest rate rule. Thus, reserve requirements might be used as a countercyclical macroprudential instrument instead of an ad-hoc policy tool that is applied during specific episodes of economic instability.

Finally, it is worth mentioning the exchange rate was incorporated in a simple 
way in a small open economy with financial frictions and reserve requirements. Future research should enrich this environment by including foreign savings funding by banks, presence of international reserves managed by the central bank, and interactions with the fiscal policy. Some of these suggestions are object of ongoing research.

\section{References}

Agénor, P.-R., Alper, K., and Pereira da Silva, L. (2013). Capital regulation, monetary policy, and financial stability. International Journal of Central Banking, 9(3):193-238.

Agénor, P.-R., Alper, K., and Pereira da Silva, L. (2015). External shocks, financial volatility and reserve requirements in an open economy. Banco Central do Brasil Working Paper, (396).

Araújo, E. (2016). Determinacy and learnability of equilibrium in a small-open economy with sticky wages and prices. International Review of Economics $\&$ Finance, 45:16-32.

Areosa, W. D. and Coelho, C. A. (2013). Using a dsge model to assess the macroeconomic effects of reserve requirements in brazil. Banco Central do Brasil Working Paper, (303).

Brei, M. and Moreno, R. (2018). Reserve requirements and capital flows in latin america. BIS Working Papers, (741).

Calvo, G. A. (1983). Staggered prices in a utility-maximizing framework. Journal of Monetary Economics, 12(3):383-398.

Carvalho, F. A. and Castro, M. R. d. (2015a). Foreign capital flows, credit growth and macroprudential policy in a dsge model with traditional and matter-of-fact financial frictions. Banco Central do Brasil Working Paper, (387).

Carvalho, F. A. and Castro, M. R. d. (2015b). Macroprudential and monetary policy interaction: a brazil perspective. Banco Central do Brasil Working Paper, (405).

Castro, M. R. d., Gouvea, S. N., Minella, A., dos Santos, R. C., and Souza-Sobrinho, N. F. (2015). Samba: Stochastic analytical model with a bayesian approach. Brazilian Review of Econometrics, 35(2):103-170. 
Christiano, L. J., Eichenbaum, M., and Evans, C. L. (2005). Nominal rigidities and the dynamic effects of a shock to monetary policy. Journal of Political Economy, 113(1):1-45.

Clancy, D. and Merola, R. (2017). Countercyclical capital rules for small open economies. Journal of Macroeconomics, 54:332 - 351. Banking in Macroeconomic Theory and Policy.

Divino, J. A. (2009a). Is there a case for domestic inflation target? Mathematics and Computers in Simulation, 79(10):3122 - 3135.

Divino, J. A. (2009b). Optimal monetary policy for a small open economy. Economic Modelling, 26(2):352 - 358.

Divino, J. A. and Kornelius, A. (2015). Política monetária e compulsório em um modelo dsge com fricções financeiras. Economia Aplicada, 19(4).

Ferreira, D. (2015). Regra de taylor e política monetária no brasil: considerações empíricas a partir de um modelo dsge para uma pequena economia aberta. Revista Teoria e Evidência Econômica, 21(44).

Ferreira, L. N. and Nakane, M. I. (2015). Macroprudential policy in a dsge model: anchoring the countercyclical capital buffer. Banco Central do Brasil Working Paper, (407).

Gali, J. (2008). Monetary policy, inflation, and the business cycle: An introduction to the new keynesian framework. Princeton University Press.

Gali, J. and Monacelli, T. (2005). Monetary policy and exchange rate volatility in a small open economy. The Review of Economic Studies, 72(3):707-734.

Gertler, M. and Karadi, P. (2011). A model of unconventional monetary policy. Journal of monetary Economics, 58(1):17-34.

Glocker, C. and Towbin, P. (2012). Reserve requirements for price and financial stability: When are they effective? International Journal of Central Banking, $8(1): 65-114$.

Glocker, C. and Towbin, P. (2015). Reserve requirements as a macroprudential instrument - empirical evidence from brazil. Journal of Macroeconomics, 44:158 $-176$

Kiley, M. T. and Sim, J. (2017). Optimal monetary and macroprudential policies: Gains and pitfalls in a model of financial intermediation. Journal of Macroeconomics, 54:232 - 259. Banking in Macroeconomic Theory and Policy. 
Montoro, C. and Moreno, R. (2011). The use of reserve requirements as a policy instrument in latin america. BIS Quarterly Review, pages 53-65.

Smets, F. and Wouters, R. (2007). Shocks and frictions in us business cycles: A bayesian dsge approach. The American Economic Review, 97(3):586-606.

West, K. D. (2003). Monetary policy and the volatility of real exchange rates in new zealand. New Zealand Economic Papers, 37(2):175-196.

Woodford, M. (2003). Interest and prices: Foundations of a theory of monetary policy. Princeton University Press. 


\section{Appendix}

Figure 7: Responses to a shock in the domestic monetary policy
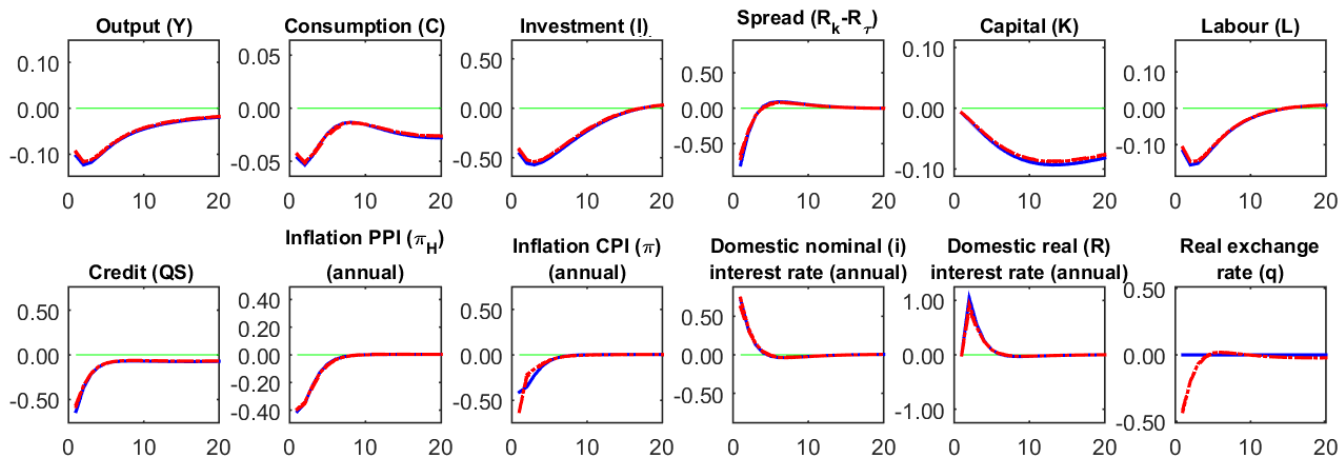

(annual)
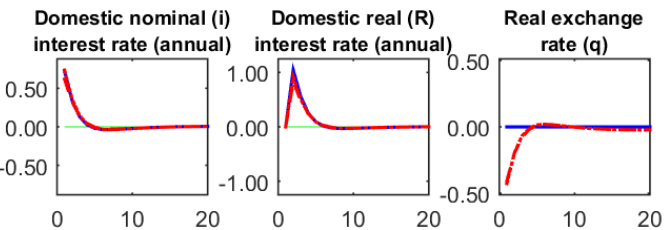

- Closed -----o---open, rule with $\pi_{\mathrm{H}}---$ Open, rule with $\pi$

Figure 8: Responses to a shock in the total factor productivity
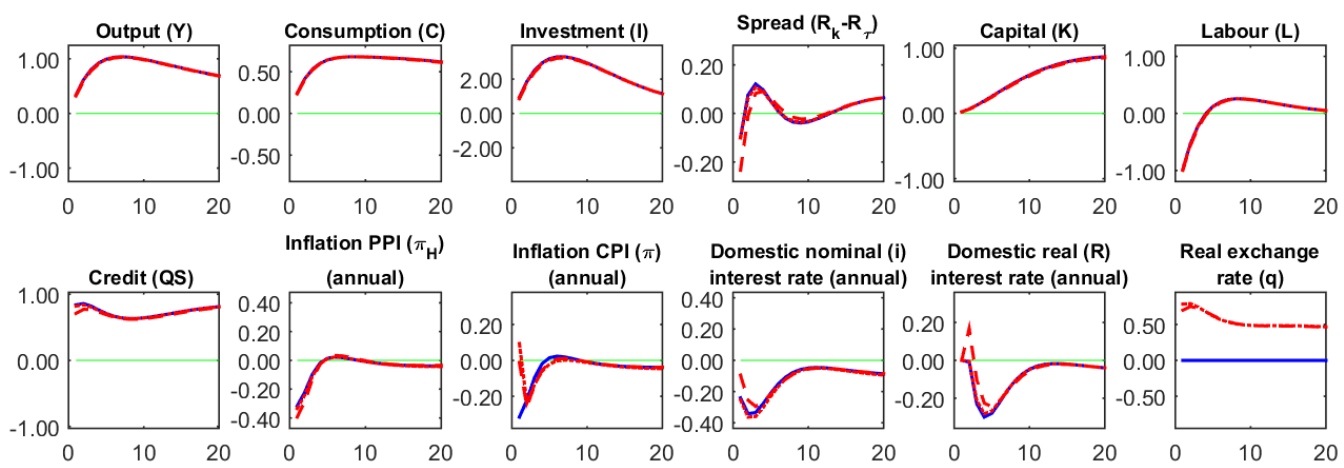

$\begin{array}{cc}\text { Domestic nominal (i) } & \text { Domestic real (R) } \\ \text { interest rate (annual) } & \text { interest rate (annual) }\end{array}$
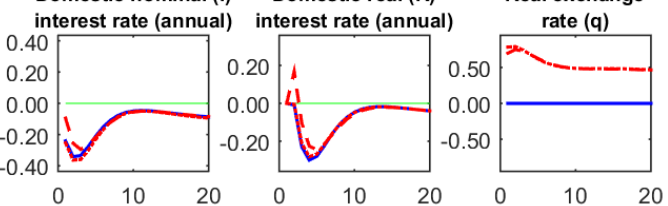

- Closed --------- Open, rule with $\pi_{\mathrm{H}}---$ Open, rule with $\pi$ 